The Geographical Journal of Nepal, Vol. 7, 2009: 23-32

\title{
Domestic Working as Gendered Space: A Study of Selected Localities in Kathmandu
}

\author{
Manira Gotame \\ Master's Student \\ Hriday L Koirala, $P h D$ \\ Associate Professor, Central Department of Geography \\ koiralah@ntc.net.np
}

\begin{abstract}
Domestic work is often considered as the women's work, but in the recent years many males have entered into this occupation. It was a customary to confine women into domestic space and thereby improving a system of both spatial control and social control on identity by males. The present paper tries to examine the socio-economic status, livelihood strategy, gender division of labor in domestic workers and the power relation with the owners and their family. The analysis is based on focus group discussion, key informant survey, observation and questionnaire survey of 63 domestic workers at several localities of Kathmandu. The findings indicated that majority of domestic workers were of 15 to 19 years of age. Many used to leave their homes for their desire of better education in the urban area. However, in terms of a livelihood strategy this occupation had rarely helped their parents economically. There existed discrepancies in work hours and types of work between male and female domestic workers. Yet, a very positive sign was that majority of domestic workers were being sent to school and allowed to use their free time study and other social activities. So, there has been a change in attitude of the owners towards them.
\end{abstract}

\section{Introduction}

Livelihood strategy can be anything that helps to sustain a life or a family. In a society, every single person struggles for the livelihood and there are several ways by which people try to make their living better. Domestic work is also not an exception. Domestic workers (DWs) or laborers are defined as the people working in the employer's (owner's) house with or without a wage for the domestic chores like washing dishes, cooking, cleaning, looking after the young children, and other household activities (Sharma, et al. 2001).

In Nepal, domestic work lies in the category of informal sector activity and therefore, the workers do not have a specific category of work, working hour, or wage. In recent years, many people in the urban areas are being employed as domestic workers, which have become an unavoidable part of urban life (Sapkota 2006). Since the past few decades, the urban society has been transformed. One is that the joint family is slowly turning into nuclear family and that such families tend to keep domestic workers as helping hands in their houses (Poudel and Sapkota 
2005). An ILO-IPEC study conducted in 2001 pointed out that there were about twenty-two thousand domestic workers in Kathmandu Valley.

Domestic work in Nepal has a long history. Kamlari, Dhai, Haliya, Kamaiya, etc are some of the terms used to denote the types of domestic workers across Nepal (Gotame 2009). Though the Government of Nepal has abolished DWs or bonded labor through adopting acts, it is not yet uncommon to observe large number of DWs in the urban areas. In the past, domestic work in the urban areas was mainly of women's work but in the recent years men have also entered into this occupation. It is generally the women who are given the responsibility for performing domestic works because they are in one way or other tied to the home and this nature has to do with both the traditional division of labor and their sex (Subedi and Baral 2008). It has almost become a trend in Nepal that only men plow, while women's work is to fetch water from public sources. Women cook, care for children, wash clothes, and collect firewood and fodder. Men perform heavier agricultural tasks and often engage in works that bring in economic sources (website: everyculture.com). Massey (1998) viewed it as the men's attempt to confine women into domestic space and thereby improving a system of both spatial and social controls on identity. However, nowadays the competition among men in so called masculine jobs has resulted in men's increasing involvement in the domestic work which is traditionally a women space. This invasion in the traditional division of labor has led complexity in the service sector, as well as in the power relation in the society. In this context, the present paper seeks to discuss the status of domestic workers in the urban areas with a particular focus on issues like livelihood, gender difference in domestic work and power relation the domestic workers share in their working place, as well as in their families.

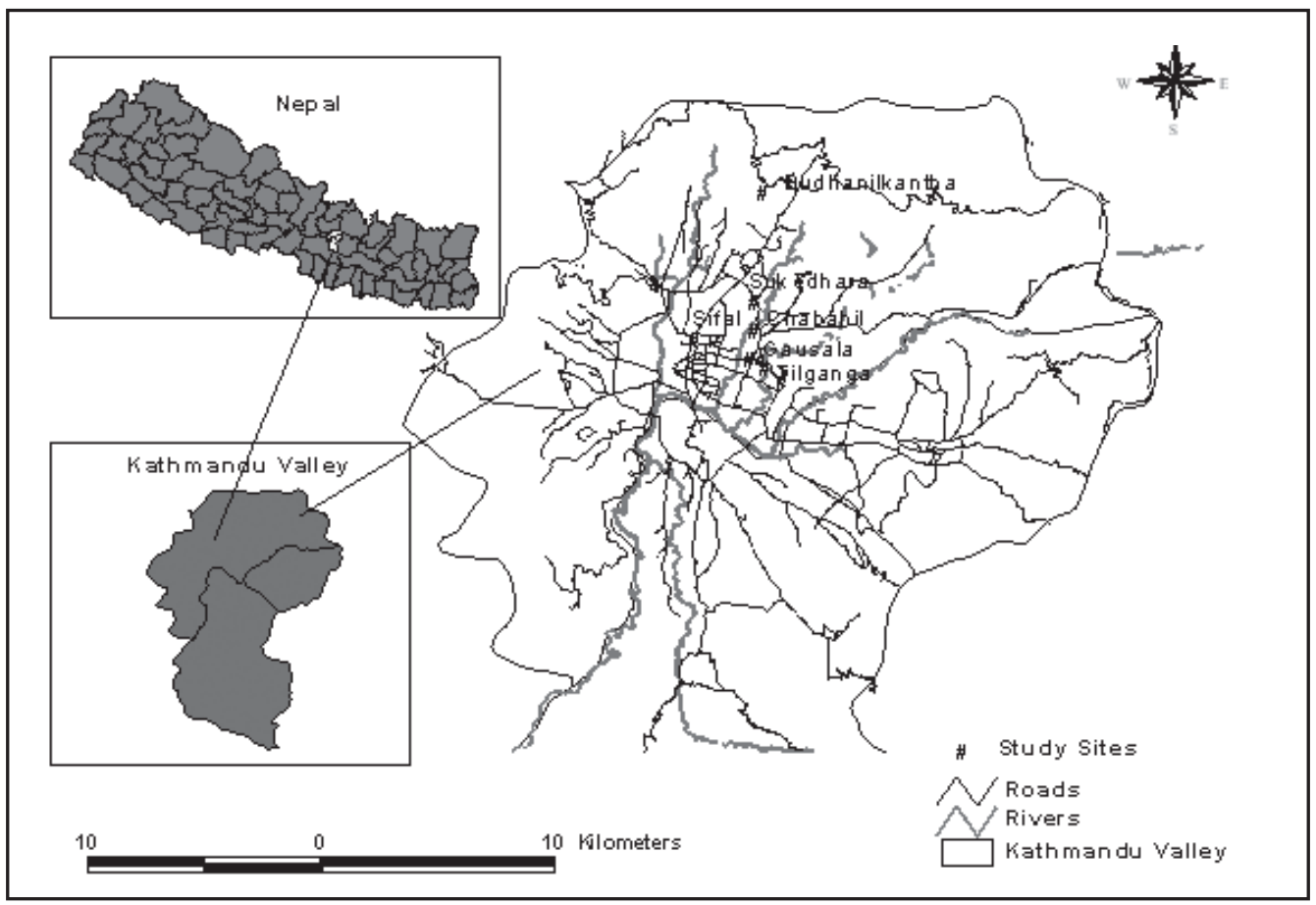

Figure 1: Study Area 


\section{Study Area and Data Base}

This study was carried out in the northern Kathmandu Valley, comprising the selected localities of Budhanilkantha, Sukedhara, Chabahil, Sifal, Gausala, and Tilganga (Fig. 1). The localities were selected due to the schools with DWs enrolment and the Children-Women in Social Service and Human Rights (CIWISH) that is being involved in awareness campaign for domestic workers.

The data for this paper were collected through questionnaire survey, focus group discussion (FGD), key informant survey (KIS), and observation survey. Altogether 63 respondents with 25 males (40\%) and 38 females (60\%) having DWs were selected as samples. In addition, 50 DWs were chosen from five higher secondary schools, namely Mitra-Chabahil, Mangaldevi-Gaushala, Bal Byabasayi-Sifal, Dhumbarahi-Sukedhara, and Sharada-Tilganga. Furthermore, 13 individual DWs from Budhanilkantha locality were selected through snowball sampling for acquiring data on working environment. A semi-structured questionnaire consisting of 34 questions was designed and administered. Based on checklists, FGD and KIS surveys were used to gather information on DWs' behavior and gender division of labor in domestic works and their physical problems during the work. FGD surveys included groups of women, men and men-women mixed. Discussions were also held with the personnel of the Nepal Independent Domestic Worker's Trade Union (NIDWU) and acquired information on pros and cons of DWs. Observation of DWs at sites was also carried out to get additional information.

\section{Origin of Domestic Workers}

As Kathmandu is the heart of the country, it draws people from different parts. However, geographical factor is the most significant one. The survey result shows that larger proportion

Figure 2: Origin of the domestic workers

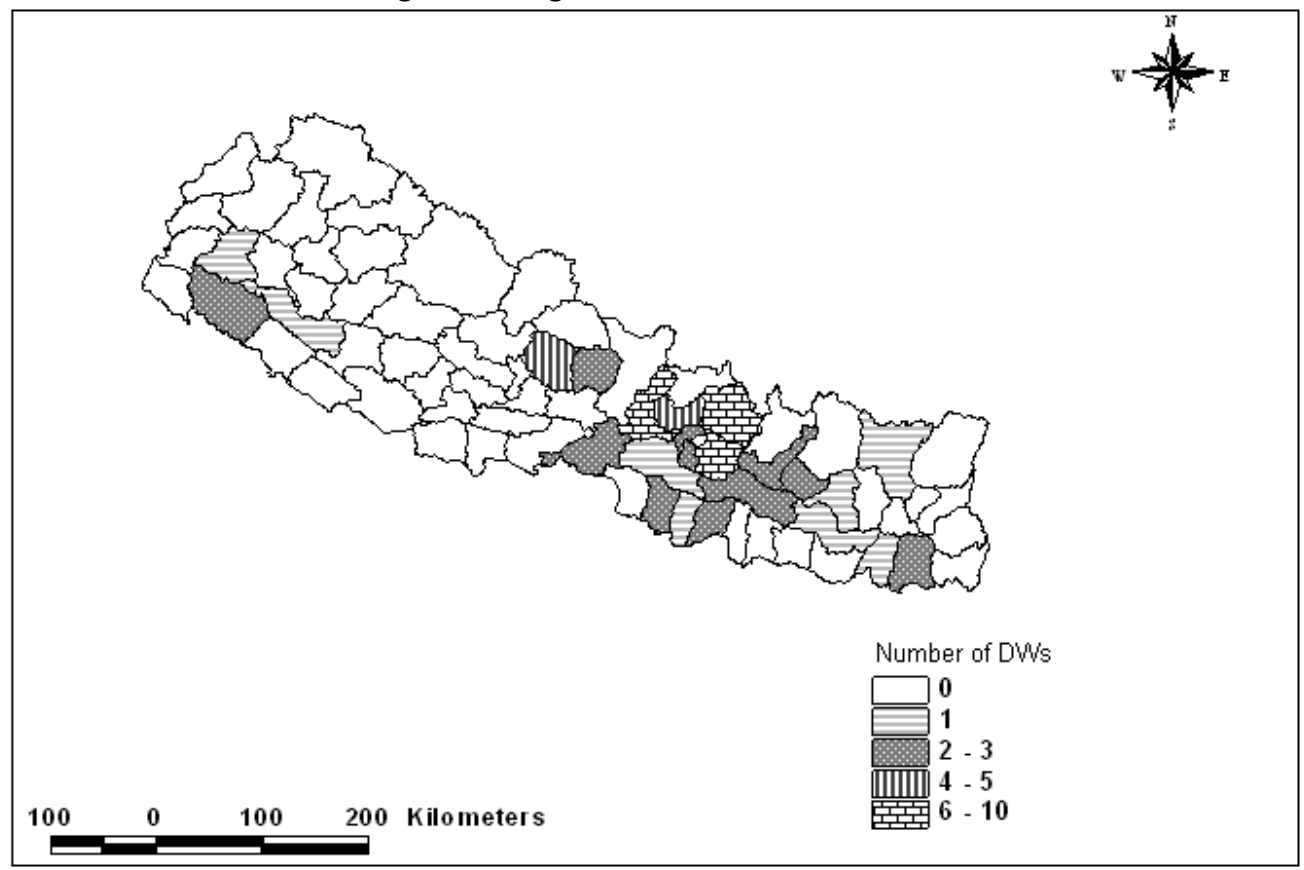

Source: Field Survey, 2008 
of DWs was from neighbouring places than the far distant places. Figure 2 shows that more than one-third of DWs was from Kathmandu's northern adjoining districts like Dhading, Sindhupalchok and Nuwakot. Some of them were from far western districts like Doti and Surkhet; many from far eastern districts like Sankhuwasabha, Sunsari, Khotang, and Udaipur, as well as from southern Tarai districts including Makawanpur, Chitwan, and Rautahat. Most of them were arrived in Kathmandu for work not by themselves but accompanied by their close relatives and with their parents' permission. Previous contact has been important to get access for work.

\section{Socio-Economic Status of the Domestic Workers}

\section{Age and Sex Characteristics}

Age and sex characteristics of a population covey its internal structure. Table 1 indicates that the profession of domestic working is age selective and only the DWs with age of 10 and above were selected for the work. Most of the DWs from the age group of 15-19 were involved in the domestic works. There is a slight increase in per cent of female DWs of 10-14 age groups over the male DWs of the same age group, which may be due to the Nepali practice that usually involves female of young age in household activities. In other age groups, men have outnumbered women in terms of percent sharing, due to physical strength of men or early marriage of women and therefore no more domestic work.

\section{Education}

Of the total of 63 DWs, 59 found to have pursuing their education at different levels, and four (only female) without attending any school. The survey data show that the males outnumbered the females in terms of relative sharing of their totals in attaining secondary and higher secondary levels, whereas the reverse

Table 1: Age and sex characteristics of domestic workers

\begin{tabular}{lcccc}
\hline Years of age & Male & Percent & Female & Percent \\
\hline Below 10 & - & - & 2 & 5.0 \\
$10-14$ & 3 & 12.0 & 5 & 13.0 \\
$15-19$ & 19 & 76.0 & 28 & 74.0 \\
Above 19 & 3 & 12.0 & 3 & 8.0 \\
\hline Total & 25 & 39.7 & 38 & 60.32 \\
\hline
\end{tabular}

Source: Field Survey, 2008 is the case at the primary level. For instance, 60 and 32 per cent of men DWs were attending the secondary and higher secondary schools, as compared to 56 and 24 per cent of women DWs respectively. At the primary school, while 20 per cent of female DWs were attending, only 8 per cent of male DWs did so. Further, most of DWs found to have completed their primary level education at their home-places and then moved to the cities for further education. Furthermore, there was negligible of dropouts of DWs.

The finding shows that DWs have main motive of attaining higher level of education, which would make them ensure of having better working in the future. There is a straight relationship between age and education level of DWs.

\section{Social Composition, Marital Status and Family Structure}

The DWs belonging to Brahmin and Chhetri were far more than those of ethnic groups; with 48 per cent of the former and 25 per cent of the latter. Compared to these hill social groups, those from the Tarai groups shared only 17 per cent. There was quite varied in the male-female ratio. In the ethnic groups, the female shared 75 percent, whereas there was more or less equal sharing between male and female in other two groups. 
One striking feature of DWs was that three-fourths of them were working in the houses of Brahmin and Chhetri groups. Another feature was that all of DWs were students and unmarried.

In case of family structure, half of the DWs were belonged to 3-6 family size at their homes which was comparable to the national average household size of 5.45. This indicates that large size families have not often worked as push factor for moving out their family members to work in the urban areas. The family size of those who have employed DWs belonged mostly to 3-6.

\section{Food Intake and Health Care}

It is argued that poverty is a cause for the people to leave their places, for the lack of works and foods. In this study, DWs found to be happy with the frequency of foods and quantity, as well as treat from their employers. The result showed that almost 35 per cent DWs had got foods thrice a day and 27 percent had two meals a day. The latter is considered to be normal by Nepali standard. Also observed was that there was less or no discrepancy in quality of foods given to DWs. In most cases, DWs had the same foods as their owners had and got to eat together with them. Men DWs were more beneficial than women DWs from such treatments. Further, most of the DWs were happy with their owners for treatments in case of illnesses or injuries.

\section{DW' relationship with their Family}

Table 2 indicates that two-thirds of DWs' parents were satisfied with their children working as domestic workers, due to the reasons that they had the opportunity to study, being involved in good work, and sometimes helped the family in social and economic terms. Over one-third of DWs' family members were unhappy, because they missed their children, forced to send them due to poor economic condition, etc.

Table 2: Family members' reaction over DWs

\begin{tabular}{lcccc}
\hline Reactions & Male's Family & Percent & Female's Family & Percent \\
\hline Satisfied & 13 & 52.0 & 25 & 65.8 \\
Unsatisfied & 12 & 48.0 & 13 & 34.2 \\
\hline Total & 25 & 100.0 & 38 & 100.0 \\
\hline
\end{tabular}

Source: Field Survey, 2008

A sixteen year old boy from Bara was working as a domestic worker for five years. Prior to this, he used to work as a coolie of carrying loads from one shop to another in his place, which did not provide adequate time to his desire of study. He joined the morning school and worked for about 8 hours after school and thus got rare time for study at working home. He often got discriminatory behaviour from his owners due to his poor economic condition and Tarai caste. He wished to earn money and look after his family. A case of a fifteen year old girl had an interesting sharing. She already spent seven years as a domestic worker, and had to look after three babies and one of them was mentally retarded, besides a regular household chore. She however could manage all the works with the help of the owners. She now had deep affection with the babies and that she did not like to leave the owner's home. What she felt was that if she left the house, her owner's family members would be in trouble, as those babies dependent more on her than their mother. 


\section{Economic Status of the Domestic Workers' Families}

The economic status of the DWs' families has been measured in terms of assets like landholding, houses and livestock. Sixty-two per cent of DWs' families had landholding ranging from 1 - 15 ropanis and the rest 38 per cent were landless. Over 86 per cent DWs' families had their own houses at their locality; many of them were Pakki. About 40 per cent had owned cows and buffaloes. All 63 DWs reported that their parents were involved in agricultural activities.

Education has been an important factor for getting access to work in the city as domestic workers. Sixteen per cent male and 29 per cent female DWs categorically reported that opting domestic work was mainly for continuity of their education in the city. Twenty-four per cent DWs claimed that domestic work was a compulsion because of their family's poor economic condition. Two cases of female DWs narrate the importance of domestic work for pursuing their education.

Case 1: An eleven year old girl from the Tharu community expressed happiness over her owner for allowing her to continue study at school. She began working as a DW recently because of extremely poor condition of her parents who also used to live in Kathmandu.

Case 2: A girl from Sindhupalchok district working as a domestic worker in Sukedhara had left her home two years ago, not because of poor condition of her parents, but due to step mother who did not allow her to continue study. She got encouragement from her owner to continue her study and had done well in her study at class four.

\section{Livelihood Assets of Domestic Workers}

Table 3 summarizes the features of five major types of livelihood assets of DWs, namely human, natural, physical, financial, and social.

An attempt has been made here to link the features of the livelihood assets of DWS with the sustainable livelihood concept of Robert Chambers (1991) and the sustainable livelihood framework of DFID (website: poverty-well being.net/media/sla/docs/2-4.htm). It seems that the DWs have gained more of human capital asset through attending schools than natural resources; these two are basic elements of livelihood concept of Chambers.

Table 3: Livelihood assets of domestic workers

\begin{tabular}{|c|c|}
\hline Assets & Status of the Domestic workers \\
\hline 1. Human assets & $\begin{array}{l}\text { - Education and health were two important human assets of DWs. They were } \\
\text { very much aware about their education, assisted by the children's club they } \\
\text { associated. Over } 95 \text { per cent DWs had attended the schools at different levels } \\
\text { in their working places. Most of them were in normal health condition, due } \\
\text { to adequate dietary foods they got at their working homes. }\end{array}$ \\
\hline 2. Natural assets & $\begin{array}{l}\text { - The natural assets of DWs were being associated to their ancestral property } \\
\text { only. Since all DWs were of young age and attaining education at working } \\
\text { places, they had not accumulated any natural assets like land, house, etc. }\end{array}$ \\
\hline 3. Physical assets & $\begin{array}{l}\text {-All DWs had owned physical assets like clothes, stationeries, living rooms, } \\
\text { etc, which they obtained from their owners. }\end{array}$ \\
\hline \multicolumn{2}{|c|}{$\begin{array}{l}\text { 4. Financial assets - Since } 95 \text { per cent of DWs had not got cash payment from their owners, as } \\
\text { they borne the expenses for their foods, school fees, living, medicine, etc. }\end{array}$} \\
\hline 5. Social assets & $\begin{array}{l}\text { - The schools attended by DWs could be considered as their social assets, } \\
\text { where they had a kind of social network. The activities organised by the } \\
\text { children's club were also their social asset. Except these, they had rarely time } \\
\text { at working homes to visit places or meet their relatives and friends. }\end{array}$ \\
\hline
\end{tabular}


The domestic workers have access to different children's club, their study and social interaction in the school which helped them to improve their human resource assets.

\section{Gender Division}

\section{Working Environment}

DWs did not have any fixed working hour and some of them found to have worked more than 8 hours a day. There was discrimination in working hour between male and female. Table 4 shows that female DWs worked more than male DWs on average. The nature of works also varied between them. Female DWs seemed to have involved in many types of work than male DWs and females Table 4: Daily working hours of domestic workers

\begin{tabular}{lcccc}
\hline Working hours & Male & Percent & Female & Percent \\
\hline Below 3 & 6 & 24.0 & 6 & 16.0 \\
3-6 & 8 & 32.0 & 16 & 42.0 \\
$6-9$ & 6 & 24.0 & 13 & 34.0 \\
Over 9 & 5 & 20.0 & 3 & 8.0 \\
\hline Total & 25 & 39.7 & 38 & 60.32 \\
\hline Source: Field Survey, 2008
\end{tabular}
generally were involved in cooking, cleaning, washing clothes, etc, while males in doing heavy works.

A working environment of a male DW is exemplified. This man from Kabhre was working at a family of two members; worked 2- 3 hours a day such as washing clothes, cleaning utensils, and marketing of rice, gas cylinder, etc. He also knew how to prepare tea as to the taste of his owners.

A main problem with all DWs was to clean dishes and wash clothes with cold water. Most of them had to ignore cuts, burns, and sickness with them, as well as to tolerate rough behavior of their owners.

\section{Work Loads}

There remained a significant difference in workloads and types between male and female DWs. Table 5 shows that female DWs were involved in all six types of works, whereas male DWs were only in three types and selective. Females had more workloads during holidays and festivals and arrival of guests. Males were also had more workloads during holidays and festivals.

Table 5: Workloads of domestic workers

\begin{tabular}{lcccc}
\hline Work types & Male & Percent & Female & Percent \\
\hline Holidays and festivals & 9 & 36.0 & 14 & 37.0 \\
Festivals & 8 & 32.0 & 8 & 21.0 \\
Arrivals of guests & - & - & 4 & 10.5 \\
Regular & 8 & 32.0 & 5 & 13.1 \\
Holidays & - & - & 3 & 7.9 \\
Festivals and arrivals of guests & - & - & 4 & 10.5 \\
\hline Total & 25 & 100.0 & 38 & 100.0 \\
\hline
\end{tabular}

Source: Field Survey, 2008 


\section{Leaves and Leisure time}

The survey revealed that 13 per cent male and 18 per cent female DWs got home leave of one - two weeks once a year and similarly other 11 per cent male and 21 per cent female also got leave for few days.

Majority of DWs found to have spent in study during leisure time. Few DWs (8\%) reported that they had seldom free time for study. However, most of DWs were happy that they were allowed to watch TV.

\section{Behavior of DWs' Owners}

Generally, the owners found to have shown good behavior to their DWs; two-thirds of DWs reported for it (Table 6). One third of DWs reported that they got scolding, threatening, discrimination, and other misbehaves from their owners. They used to get such behaviours when the assigned works given to them got spoiled. In some cases, the owners used to behave in a good manner to them during the time of visit of their relatives and parents to them and in other cases, they were not so good. Two examples of owners' behaviour are cited here.

Table 6: Owners' behavior to domestic workers

\begin{tabular}{lcccc}
\hline Behaviors & Male & Percent & Female & Percent \\
\hline Good & 16 & 64.0 & 25 & 65.8 \\
Scolding & 6 & 24.0 & 7 & 18.4 \\
Scolding and threatening & - & - & 3 & 7.9 \\
Nature of owners' members & - & - & 3 & 7.9 \\
Discriminative & 3 & 12.0 & - & - \\
\hline Total & 25 & 100.0 & 38 & 100.0 \\
\hline
\end{tabular}

Source: Field Survey, 2008

A fifteen years boy from Sunsari who were working as a DW for more than three years shared his view regarding his owners' behaviour to him. He often used to get rough behaviour in terms of words from his owner and he got normal behaviour from his owner when his relatives visited him. On the contrary, experience of a Gurung girl was quite different. According to her, she spent as a DW more than 10 years now and was a student of class nine due to wish of her owners. She also got citizenship last year with the help of her owners. This would make her easy to get further study or work abroad if she wished.

\section{Conclusion}

Most of the DWs were economically poor, but their main priority to work as domestic worker was to achieve better and further education into urban area. They were found to work as domestic workers mostly by their parents' choice. However, due to limited and no income out of domestic workers they could not support their families back home. 
Gender division remains to have prevailed even in the domestic workers, too. It is mostly the women who are preferred as domestic workers by the owners. However, there is discrepancy in work hours and work types between males and females. Recently many males have entered into the domestic working space, which means that the invasion of male domestic workers into this occupation has helped to lessen the gap in the division of labour between men and women.

A very positive sign is that majority of the domestic workers are being sent to school. They are allowed to use their free time in social activities as well. There is a change in the owners' way of behaviour to their domestic workers. This shows a change of attitude of the owners towards DWs. This change may be a positive start to see the working class people. It may be a beginning to accept a change in the power relation people shared traditionally.

\section{References}

Ahmed, F (2001), Gender division of labor: Bangladesh context. Unnayan Podokkhep. http:// www.adhunika.org/links/index.html (Retrieved on $4^{\text {th }}$ Feb, 2009)

Chambers, R and Conway, G (1991), Sustainable Rural Livelihoods: Practical Concepts for the $21^{\text {st }}$ Century. IDS Discussion Paper 296. University of Sussex, Institute for Development Studies.

Gotame, M (2009), Domestic Workers in their Living: A Study of Selected Localities in Kathmandu District. Master's Thesis. Kathmandu: Central Department of Geography, Tribhuvan University.

Massey, D (1998), Space, Place and Gender. Cambridge: Polity.

Poudel, R K and Sapkota, B P (2005), Gharelu Balshram Parichaya. Kathmandu: GEFONT and Children-Women in Social Service and Human Rights (CWISH).

Pokharel, B and Mishra, M (2001), Gender and democracy in Nepal. In: Manandhar, L K and

Bhattachan, K B (Eds.), Gender and Democracy in Nepal. Kathmandu: Central Department of Home Science/Women's Studies, Tribhuvan University. pp: 3-12.

Sapkota, B P (2006), Gharelu Shramik Sashaktikaran Tatha Sangathan Nirman Nirdeshika. Kathmandu: GEFONT and CWISH.

Sharma, S, Thakurathi, M, Sapkota, K, Devkota, B, and Rimal, B (2001), Situation of Domestic Child Laborers in Kathmandu: A Rapid Assessment. Kathmandu: ILO-IPEC.

Subedi, B P and Baral, N D (2005), Female tempo drivers in Kathmandu: challenging gendered space for livelihood and identity. The Geographical Journal of Nepal. 6: 1 -17. 
United Nations Commission on Human Rights, (2002), The Relationship between Child Domestic Servitude and the Sexual Exploitation of Children. http://www.antislavery.org/homepage / resources/publication.htm (Retrieved on $8^{\text {th }}$ Sep 2008)

Wadley, S S (1997), Women and National Development: the Complexities of Change. Stanford CA: Stanford University Press. pp: 17-42.

www.poverty-wellbeing.net/media/sla/docs/2-4.html (Retrieved on $8^{\text {th }}$ Sep, 2008).

www.everyculture.com/Ma-Ni/Nepal.html (Retrieved on $9^{\text {th }}$ Sep, 2007) 